\title{
Intraventricular Administration of Antibodies to Nerve Growth Factor Retards Kindling and Blocks Mossy Fiber Sprouting in Adult Rats
}

\author{
Catharina E. E. M. Van der Zee, ${ }^{1}$ Kashif Rashid, ${ }^{1}$ Khoa Le, ${ }^{1}$ Karen-Ann Moore, ${ }^{2}$ Jolanta Stanisz, ${ }^{1}$ Jack \\ Diamond, ${ }^{1}$ Ronald J. Racine, ${ }^{2}$ and Margaret Fahnestock \\ ${ }^{1}$ Department of Biomedical Sciences and ${ }^{2}$ Psychology Department, McMaster University, Hamilton, Ontario, Canada \\ L8N $3 Z 5$
}

Repeated subconvulsive electrical stimulation of certain areas of the forebrain leads to kindling, a progressive and permanent amplification of evoked epileptiform activity, which is a model for human temporal lobe epilepsy. Recent studies have shown that kindling induces synthesis of nerve growth factor (NGF) and brain-derived neurotrophic factor (BDNF) but not neurotrophin-3 (NT-3) in the hippocampus and cortex. Kindling also elicits mossy fiber sprouting and functional synaptogenesis in the supragranular layer, the hilus, and the CA3 region of the hippocampus. Intraventricular administration of antibodies to NGF has been shown to effectively block septohippocampal sprouting in the adult rat, and has been reported to retard amygdaloid kindling. In the present study, we have investigated the possible role of NGF in both kindling and kindling-associated sprouting. We have confirmed a kindlinginduced sprouting of the mossy fibers into the stratum oriens of the CA3 region of the hippocampus, utilizing a new semiquantitative method of analysis based on Timm staining. Previous studies found no overt signs of hippocampal damage with this kindling paradigm, indicating that the increased Timm staining likely reflects a purely activity-induced sprouting. Intraventricular infusion of affinity-purified anti-NGF IgGs (which cross-react with NT-3 but not BDNF) resulted in both significant retardation of kindling and inhibition of the kindling-induced mossy fiber sprouting. The findings suggest a role for NGF in both these phenomena.

[Key words: anti-NGF, mossy fibers, sprouting, kindling, intraventricular administration, adult rat, neurotrophin]

Kindling is a phenomenon in which repeated low-intensity (subconvulsive) electrical stimulation of forebrain areas leads to a progressive and permanent amplification of the evoked epileptiform discharge and the eventual development of convulsive activity (Racine, 1972; Racine and Burnham, 1984). It has been

Received July 1, 1994; revised Feb. 27, 1995; accepted Mar. 8, 1995.

We thank Qin Lu for her help with the bioassays and Ross Ridsdale for his assistance with the figures. This work was supported by a grant from the Canadian Natural Science and Engineering Research Council to R.J.R. and the NeuroSciences Network of Centres of Excellence to J.D. The support of the DeGroote Foundation to M.F. is gratefully acknowledged.

Correspondence should be addressed to Dr. Margaret Fahnestock, Department of Biomedical Sciences, McMaster University, 1200 Main Street West, IIamilton, Ontario, Canada L8N $3 Z 5$.

Copyright (C) 1995 Society for Neuroscience 0270-6474/95/155316-08\$05.00/0 widely accepted as a model for human temporal lobe epilepsy, particularly the secondary generalization of complex partial seizures. During the development of kindling, sprouting of the hippocampal mossy fibers (i.e., axons of the dentate gyrus granule cells) has been observed in the supragranular layer (Sutula et al., 1988; Cavazos et al., 1991), the hilus (Represa et al., 1993), and in the CA3 region (Represa and Ben-Ari, 1992) of the hippocampus. These new neurites appear to establish synaptic connections (Represa and Ben-Ari, 1992; Represa et al., 1993). Mossy fiber synaptic reorganization has also been described in the epileptic human temporal lobe (Sutula et al., 1989; Houser et al., 1990; Houser, 1992; Masukawa et al., 1992).

The mechanism of the progressive development of seizure activity and of kindling-induced sprouting is unknown. In the case of perforant path kindling, there is some loss of neurons in the hilus of the dentate gyrus (Sloviter, 1987; Cavazos et al., 1994; Spiller and Racine, 1994) and in CA1 (Cavazos et al., 1994). This cell loss increases with repeated seizures. Loss of neurons with a concomitant disappearance of axons in the molecular layer and CA3-CA4 areas could act as a trigger for sprouting (see Diamond et al., 1992). Thus far, it is not clear whether amygdala kindling produces cell loss in conjunction with mossy fiber sprouting. Cavazos et al. (1994) reported loss of neurons in animals in which large numbers of amygdala kindled seizures had been triggered. However, Represa et al. (1989) and Represa and Ben-Ari (1992) reported sprouting in amygdala kindled animals with no accompanying cell loss. No signs of degenerating cells were found following amygdala kindling, using a sensitive cupric/silver stain (M. Khurgel, R. C. Switzer, G. C. Teskey, A. E. Spiller, R. J. Racine, and G. O. Ivy, unpublished observations). It remains to be seen, then, whether kindling-induced sprouting represents a purely activation-induced phenomenon.

Neurotrophins such as nerve growth factor (NGF) and brainderived neurotrophic factor (BDNF) also seem likely to play an important role in kindling and in kindling-associated synaptic reorganization. Kindling-induced seizures lead to a rapid, transient increase of NGF and BDNF mRNAs and NGF protein in the dentate gyrus and parietal and piriform cortices (Ernfors et al., 1991; Bengzon et al., 1992, 1993; Dugich-Djordjevic et al., 1992), whereas neurotrophin-3 (NT-3) mRNA remains unchanged (Ernfors et al., 1991) or is reduced (Bengzon et al., 1993). TrkB (BDNF receptor) mRNA and protein are also induced in the hippocampus after kindling (Merlio et al., 1993). Lowenstein et al. (1993) reported an increase in neurotrophic activity, using 
a chick dorsal root ganglia (DRG) bioassay, in rat hippocampal extracts after kainic acid (KA) induced seizures. Changes in neurotrophin expression (Ernfors et al., 1991) have also been correlated with changes in the excitatory glutamate and inhibitory gamma-aminobutyric (GABA) transmitter systems (Zafra et al., 1991; Lauterborn et al., 1993), which have both been proposed to be involved in kindling (Sato et al., 1990). In addition, cholinergic systems, which are known to be regulated by NGF (Barde, 1989), can influence kindling epileptogenesis (Arnold et al., 1973; Cain, 1983; Westerberg and Corcoran, 1987; Cain et al., 1988). The possibility that neurotrophins might be causally involved in kindling was demonstrated by Funabashi et al. (1988), who reported that anti-NGF administration delays the development of amygdaloid kindling.

The role of NGF in CNS sprouting is well established. Exogenous NGF evokes axonal outgrowth in the lesioned septohippocampal pathway (Hagg et al., 1990), while intraventricular anti-NGF administration blocks collateral sprouting of septohippocampal fibers following entorhinal cortex lesions (Van der Zee et al., 1992). Thus, it seems possible that induction of NGF, and possibly other neurotrophins, is required for kindling-induced sprouting, and that this sprouting actually contributes to the development or persistence of the kindled state. In this study, we examined whether treatment by a well-characterized antibody to NGF would result in inhibition of both mossy fiber sprouting and kindling.

\section{Materials and Methods}

\section{Animals}

Male Long-Evans hooded rats, 300-400 gm, were housed individually, maintained on an ad libitum feeding schedule, and kept on a $12 \mathrm{hr}$ on/12 hr off light cycle.

\section{Surgery: electrode implants and intraventricular cannulation}

The rats were anesthetized with ketamine hydrochloride $(100 \mathrm{mg} / \mathrm{kg})$ and xylocaine hydrochloride $(10 \mathrm{mg} / \mathrm{kg})$ and placed in a stereotaxic holder. Bipolar electrodes, made from teflon-coated, stainless steel wires (diameter $190 \mu \mathrm{m}$ ), were implanted into the right amygdala. The stereotaxic coordinates, selected from Paxinos and Watson (1982), were $2.8 \mathrm{~mm}$ posterior and $4.8 \mathrm{~mm}$ lateral to bregma, and $8.6 \mathrm{~mm}$ ventral to brain surface. Immediately after the electrode implantation, a cannula was implanted into the lateral ventricle, $5 \mathrm{~mm}$ below the skull surface, at $0.6 \mathrm{~mm}$ caudal to bregma and $1.3 \mathrm{~mm}$ lateral to the midline. It was firmly attached to the skull with dental cement, and anchored with three stainless steel screws. An osmotic pump (Alzet model 2002, flow speed $0.5 \mu \mathrm{l} / \mathrm{hr}$, effective maximally $14 \mathrm{~d}$ ), connected to the cannula via polyethylene tubing and placed subcutaneously in the neck area, delivered $100 \mu \mathrm{g} / \mathrm{d}$ affinity-purified anti-NGF or control serum IgGs. Histological examination of coronal sections containing lateral ventricle or amygdala was done at the end of one experiment $(n=3)$ to confirm correct placement of the cannula and the electrode, respectively. The animals were given $3 \mathrm{~d}$ recovery after surgery, before the kindling paradigm was started.

\section{Kindling paradigm}

Stimulation evoked afterdischarges. All animals received a.1 sec train of $1 \mathrm{msec}$ pulses at a frequency of $60 \mathrm{~Hz}$ and a pulse intensity of 200$400 \mu \mathrm{A}$. This low-intensity stimulation was sufficient to trigger an epileptiform afterdischarge (AD) after each such stimulation. Rats were stimulated twice per day over a period of $11 \mathrm{~d}$, and the duration and magnitude of the afterdischarges were recorded electrophysiologically.

Behavioral seizures. Progression of kindling was also monitored behaviorally, twice per day for $11 \mathrm{~d}$, by recording the behavioral seizure stage after each stimulation. Behavior was rated on a scale of 1 to 5 according to Racine (1972): (1) mouth and facial twitches, (2) clonic head movements, (3) forelimb clonus, (4) clonic rearing, (5) loss of postural control (falling). Animals were regarded as fully kindled when they exhibited three consecutive stage- 5 seizures. Animals that failed to
Table 1. Ability of anti-NGF IgG to block neurotrophin-induced neurite outgrowth

\begin{tabular}{ll}
$\begin{array}{l}\text { Average number } \\
\text { of neurites } \\
\text { (range) }\end{array}$ & $\begin{array}{l}\% \text { Inhi- } \\
\text { bition }\end{array}$ \\
\hline
\end{tabular}

\begin{tabular}{lcc}
\hline Superior cervical ganglia & & \\
NGF & $64(62-65)$ & 100 \\
NGF + anti-NGF IgG & 0 & \\
Dorsal root ganglia & $132(120-143)$ & \\
NGF & 0 & 100 \\
NGF + anti-NGF IgG & $58(54-61)$ & \\
BDNF & $48(44-52)$ & 17 \\
BDNF + anti-NGF IgG & $52(47-57)$ & \\
NT-3 & $1(0-2)$ & 98 \\
NT-3 + anti-NGF IgG & & \\
Nodose ganglia & $136(109-163)$ & \\
BDNF & $135(133-136)$ & $<1$ \\
BDNF + anti-NGF IgG &
\end{tabular}

Recombinant NGF, BDNF, or NT 3, affinity purified from baculovirus-infected insect cell cultures, was used in a bioassay at a concentration evoking maximal neurite outgrowth. Neurotrophic factors, with or without affinity-purified sheep anti-NGF IgG $(10 \mu \mathrm{g} / \mathrm{ml})$, were added to dissociated mouse superior cervical, dorsal root, or nodose ganglion neurons. After $48 \mathrm{hr}$, the number of neurons exhibiting neurites with lengths greater than twice the cell body diameter were counted in each dish. The numbers represent the average of two dishes and their range. The percentage inhibition exerted by anti-NGF IgG is one minus the average number of neurites in the presence of anti-NGF IgG divided by the number of neurites in the absence of the antibody.

reach stage 5 after 22 stimulations were assigned a value of 22 for the purpose of calculating kindling rate.

\section{Anti-NGF antibody preparation, $\operatorname{Ig} G$ purification, and characterization}

NGF (2.5S) was prepared from male mouse salivary glands according to the method of Mobley et al. (1976), and further purified by HPLC according to Petrides and Shooter (1986). The ability of purified NGF to promote neurite outgrowth was determined using cultures of dissociated mouse superior cervical ganglion neurons (Coughlin and Collins, 1985). To obtain antibodies, sheep were immunized with $0.5 \mathrm{mg}$ of $2.5 \mathrm{~S}$ NGF intradermally (5-10 sites) in complete Freund's adjuvant initially, and in incomplete adjuvant every 4 weeks thereafter.

Blood $(150 \mathrm{ml} / \mathrm{animal})$ was collected $10 \mathrm{~d}$ after each booster injection. Serum was prepared by clotting the blood at room temperature followed by centrifugation at $1,500 \times \mathrm{g}$ for $30 \mathrm{~min}$, heat inactivation at $56^{\circ} \mathrm{C}$ for $30 \mathrm{~min}$, and sterilization using $0.22 \mu \mathrm{m}$ filters (Nalge Company, Rochester, NY). To determine serum titers of anti-NGF preparations, serial dilutions of the antiserum in culture medium were combined with equal volumes of medium containing $20 \mathrm{ng} / \mathrm{ml} 7 \mathrm{~S}$ NGF and incubated at $37^{\circ} \mathrm{C}$ for $1 \mathrm{hr}$. Sheep preimmune serum was used as control serum. IgG was purified from serum by differential precipitation, using caprilic acid followed by ammonium sulfate (McKinney and Parkinson, 1987). NGF-specific antibody was further purified using affinity chromatography on 2.5S NGF coupled to $\mathrm{CN}-\mathrm{Br}$ Sepharose 4B (Pharmacia).

Specificity of biological activity of anti-NGF IgG was determined by studying its ability to block neurotrophin-induced neurite outgrowth in a neurite outgrowth bioassay (Coughlin and Collins, 1985; Yamamori, 1992). The anti-NGF IgG neutralizes the activity of purified mouse $7 \mathrm{~S}$ NGF half-maximally at a concentration of $0.1 \mu \mathrm{g} / \mathrm{ml}$ and completely at a concentration of $0.5 \mu \mathrm{g} / \mathrm{ml}$. Recombinant NGF, BDNF, or NT-3 from baculovirus-infected insect cell cultures was used to test the inhibitory effects of the anti-NGF IgG on dissociated superior cervical ganglion, dorsal root ganglion, or nodose ganglion neurons from newborn (day 1) mice (see also legend Table 1).

\section{Timm histochemistry}

The Timm staining procedure was used to stain the $\mathrm{Zn}^{2+}$-containing mossy fibers. At day 15 postsurgery, rats were anesthetized with sodium pentobarbital $(65 \mathrm{mg} / \mathrm{kg}$ ) and perfused transcardially (the descending 
aorta was clamped off) with $50 \mathrm{ml}$ sodium sulfide perfusion medium (8.9 gm Na $25 \cdot 9 \mathrm{H}_{2} \mathrm{O}, 10.9 \mathrm{~g}$ sucrose, $1.19 \mathrm{~g} \mathrm{Na}_{2} \mathrm{PO}_{4} \cdot \mathrm{H}_{2} \mathrm{O}$ per $100 \mathrm{ml}$ ). The brains were removed, covered with Tissue-Tek ${ }^{\circledR}$ (Miles Inc. Diagnostics Division, Elkhart, IN) and immediately frozen on dry ice. Horizontal $36 \mu \mathrm{m}$ sections of the hippocampal area at $4.1-4.6 \mathrm{~mm}$ ventral to bregma were cut on a cryostat and mounted on chromium potassium sulfate (chrom alum)-coated slides. The sections were developed in the dark for $60-80 \mathrm{~min}$ in a $60: 30: 10 \mathrm{ml}$ mixture of gum arabic $(50 \mathrm{gm} / 100$ $\mathrm{ml})$, hydroquinone $(5.67 \mathrm{gm} / 100 \mathrm{ml})$, and citric acid $(6.375 \mathrm{gm} / 25 \mathrm{ml})$ sodium citrate $(5.875 \mathrm{gm} / 25 \mathrm{ml})$ buffer; $0.5 \mathrm{ml}$ of a silver nitrate solution $\left(1.7 \mathrm{gm} \mathrm{AgNO}_{3} / 10 \mathrm{ml}\right.$ ) was added per $100 \mathrm{ml}$ developing mixture (Danscher, 1981; Sutula et al., 1988).

\section{Quantification of distribution of Timm granules in the stratum oriens}

Mossy fiber sprouting was evaluated by comparing the density of Timm granules in the stratum oriens of kindled rats receiving control serum or anti-NGF IgGs with the density values of the stratum oriens of control animals. The group of control animals consisted of seven nonkindled rats without an implanted electrode and three unstimulated rats with an implanted electrode. Neither control group had an implanted cannula. Density measurements of electrode-implanted nonkindled control rats did not differ from the nonimplanted, nonkindled control rats. The horizontal sections from the dorsal hippocampus were examined at $100 \times$ magnification by creating a digitized image (monitor screen 19 $\times 25 \mathrm{~cm}$ ), utilizing an innage analysis system (Micro Computer Inaging Device, Brock Univ., St. Catharines, Ont., Canada). The maximum density value range in this system was $0-256$. The density of Timm granules was measured at 20 adjacent positions along the extent of the stratum oriens (see Fig. $2 D$ ). Background values were provided by readings at 10 cursor placements in the stratum radiatum of the CA3. All density readings of the strata oriens and radiata were within the linear range of 110-200. The initial statistical analyses were done on the raw density values (see Fig. 3).

In order to account for variations in background Timm staining density from section to section, and still be able to compare the density of the strata oriens Timm staining in the different sections, we constructed a standard curve. We measured the density of Timm granules in the stratum oriens and the background density in the stratum radiatum of seven nonkindled control rats. A total of 80 correlated values (seven rats; 10-12 hippocampal sections/rat) was plotted and a regression line curve fit was calculated to provide a standard curve of density in the stratum oriens versus background density in the stratum radiatum (see Fig. 4). Next, the density of Timm granules in the stratum oriens and the background density of the stratum radiatum of both the control serum $\operatorname{IgG}(n=5)$ and the anti-NGF $\operatorname{IgG}(n=6)$ treated kindled rats (9-14 hippocampal sections/rat) were measured. A group of anti-NGF IgG infused, electrode-implanted but nonkindled rats $(n=5)$ was studied as well. The density of the stratum oriens of the kindled brain sections was compared with the stratum oriens density values of nonkindled control brain sections with the same background density value, using the standard curve in Figure 4. The stratum oriens Timm granules density in kindled rats was expressed as percentage increase (in density) compared to control nonkindled rats (see Fig. 5):

percentage increase

$$
=\frac{\text { experimental density value }- \text { control density value }}{\text { control density value }} \times 100
$$

\section{ChAT immunocytochemistry, optical density measurement}

The buffers used for perfusion and immunocytochemical staining were phosphate-buffered saline (PBS, $\mathrm{pH} 7.2$ ) and $0.1 \mathrm{M}$ phosphate buffer (PB, pH 7.3)

For ChAT immunocytochemistry, rats received a 2 week intraventricular infusion of control serum IgG $(n=4)$, anti-NGF IgG $(n=4)$ or no treatment $(n=3)$, and were subjected to the same amygdala kindling paradigm as described above. Another control group consisted of three nonkindled, noninfused animals. After 2 weeks, the rats were perfused with $4 \%$ paraformaldehyde, $4 \%$ picric acid in PB. The brains were removed, postfixed for $3 \mathrm{hr}$, washed in PB (three changes), and stored overnight. Coronal $50 \mu \mathrm{m}$ vibratome sections of the entire basal forebrain were cut. The free-floating sections were incubated for $1 \mathrm{hr}$ in a blocking solution containing $5 \%$ heat-inactivated normal horse se- rum and $0.3 \%$ Triton $\mathrm{X}-100$ in $\mathrm{PB}$ at room temperature, then incubated overnight in a 1:600 dilution of the anti-ChAT primary antibody (Chemicon Int. Inc., Temecula, CA) in blocking solution. The following day, the sections were washed in PBS for $2 \mathrm{hr}$ (six changes), then incubated for $2-3 \mathrm{hr}$ in a 1:200 dilution of secondary antibody (biotinylated goatanti-rabbit, Dimension Laboratories Inc., Mississauga, Ont., Canada) in $1.5 \%$ heat-inactivated normal horse serum in PB. The sections were washed for $1 \mathrm{hr}$ in PBS (three changes), then incubated for $1 \mathrm{hr}$ in a 1:100 dilution of avidin-biotin horseradish peroxidase (Dimension Laboratorics Inc.) in PB, followed by a $1 \mathrm{hr}$ wash in PBS (three changes). Finally, each set of sections was immersed for $5 \mathrm{~min}$ in $0.05 \% \mathrm{DAB}$, $0.02 \%$ hydrogen peroxide in PB and rinsed in PBS.

The ChAT-positive cell bodies in the medial septum and vertical diagonal band of Broca from 10-13 sections of each rat brain were identified at a magnification of $100 \times$. The number and optical density of all ChAT-positive cells visible on the screen image in each of these sections were measured, using an image-analysis system (MCID: Micro Computer Imaging Device, Brock Univ., St. Catharines, Ont., Canada).

\section{Statistical analysis}

An ANOVA with repeated measures and a supplemental $t$ test was performed to compare the number of stimulations needed to reach stage 5 seizures, and the Student's $t$ test was used for comparison of the average number of stimulations required for control serum and antiNGF-treated kindled rats. A one-way ANOVA with a supplemental $t$ test was applied for the comparison of the average optical densities of ChAT immunocytochemically stained basal forebrain cell bodies and for comparison of the stratum oriens Timm staining density data; the Student's $t$ test was applied to compare the average percentage increase in density values of the two groups of kindled rats.

\section{Results}

Anti-NGF IgG blocks NGF-induced, but not BDNF-induced, neurite outgrowth

The ability of anti-NGF IgG to completely block NGF-induced neurite outgrowth in an in vitro bioassay of mouse superior cervical and dorsal root ganglia is shown in Table 1. Anti-NGF IgG did not block BDNF-induced neurite outgrowth from mouse nodose ganglion neurons, and only slightly blocked outgrowth from dorsal root ganglion neurons. The anti-NGF IgG also blocked NT-3-induced neurite outgrowth in dorsal root ganglion neurons (Table 1).

\section{Anti-NGF treatment delays kindling-induced seizures}

Intraventricular infusion of anti-NGF for 2 weeks resulted in significant retardation of kindling. Rats were stimulated twice a day over an $11 \mathrm{~d}$ period, beginning $3 \mathrm{~d}$ after electrode and cannula implantation. In animals that received intraventricular antibodies to NGF, the number of stimulations needed to reach stage 5 seizures was significantly greater than for rats receiving control serum IgGs. Three of the 12 anti-NGF-treated rats failed to reach stage 5 during the kindling phase and were assigned a value of 22 stimulations. The average number of stimulations required to reach stage 5 seizures (or 22 stimulations) was 16.4 \pm 1.1 for 12 anti-NGF-treated rats, as compared to $10.4 \pm 1.0$ for 9 control animals ( $p<0.001$; Fig. $1 A$ ), confirming the previous results of Funabashi et al. (1988). This retardation of kindling was seen at all five stages [Fig. $1 B ; F(1,19)=28.27, p<$ $0.001]$.

\section{Mossy fiber sprouting in hippocampal area CA3 of kindled rats}

Figure 2 shows representative examples of horizontal Timmstained sections of area CA3 of a nonkindled control rat $(A)$, a control serum $\operatorname{lgG}$ treated kindled rat $(B)$, and an anti-NGF IgGtreated kindled rat $(C)$. Timm granules are clearly increased in 

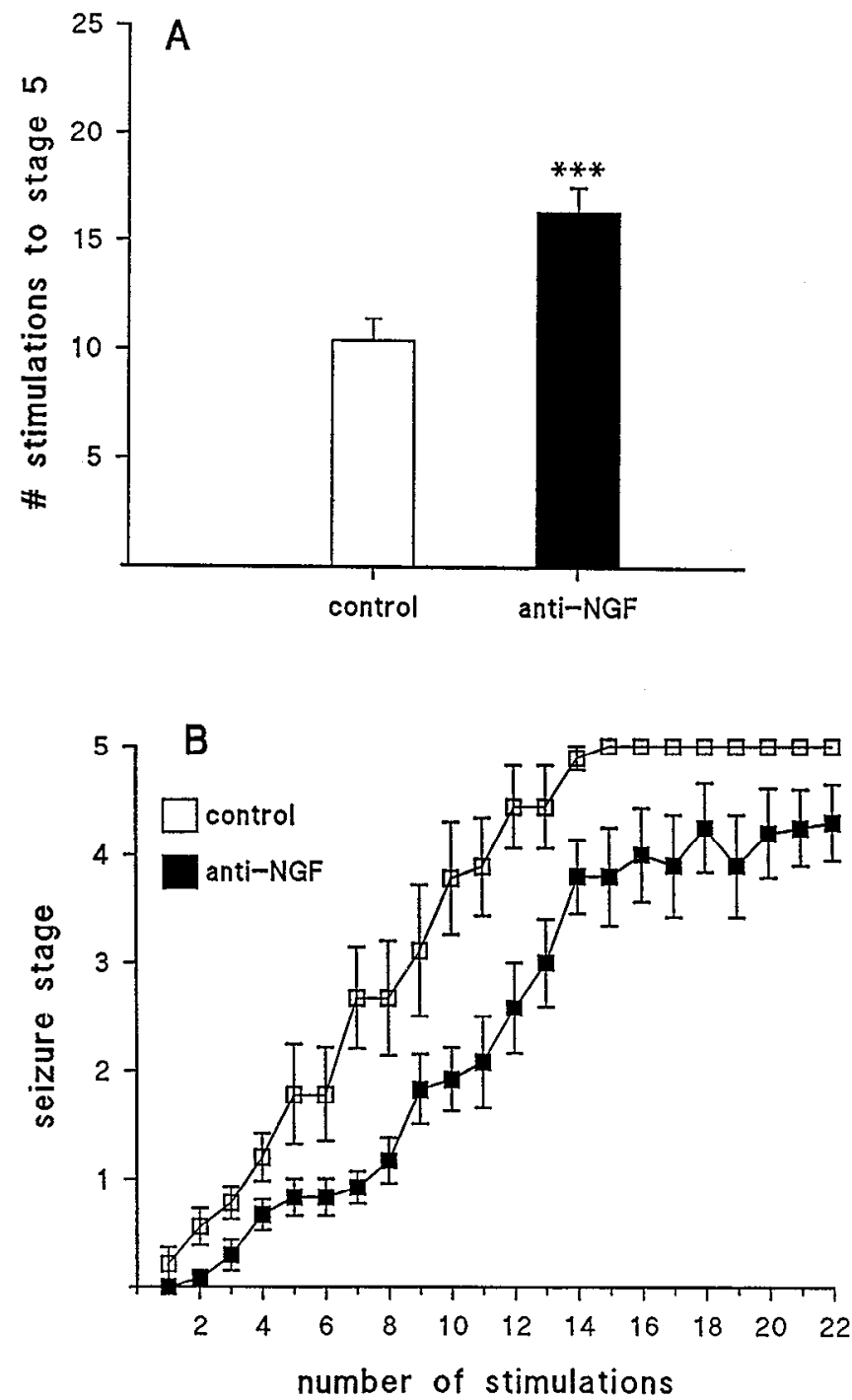

Figure 1. Intraventricular anti-NGF IgG treatment delays kindlinginduced seizures. $A$, Anti-NGF IgG-treated rats $(n=12)$ require a significantly higher number of stimulations to reach seizure stage 5 (or 22 stimulations) compared to rats receiving control serum IgGs $(n=9)$. $B$, Anti-NGF IgG-treated rats show a retardation of amygdaloid kindling at all five stages. $* * *$, statistical significance $(p<0.001)$.

the stratum oriens of the control serum IgG-treated kindled rat, when compared with the nonkindled rat.

The average Timm stain density values of the stratum oriens of nonkindled control $(n=7)$, anti-NGF IgG-treated nonkindled $(n=5)$, control serum IgG-treated kindled $(n=5)$, and antiNGF IgG-treated kindled $(n=6)$ rats are significantly different, as shown in Fig. 3 [ANOVA, $F(3,22)=39.72, p<0.0001$ ]. The control serum IgG-treated kindled rats showed a significantly higher density of Timm granules in the stratum oriens compared to control nonkindled rats (Fig. $3, p<0.001$ ). Density measurements of electrode-implanted nonkindled control rats $(n$ $=3$ ) did not differ from the nonimplanted, nonkindled control rats $(n=7$; data not shown).

The density values of the stratum oriens and the stratum radiatum (background) measurcd in the seven nonimplanted, nonkindled control rats were used to create a standard curve for stratum oriens Timm granule density comparisons (Fig. 4; see also Materials and Methods). The comparisons in Figure 5 were referenced to this standard curve. In Figure 5, the increase in the Timm granule density for the two kindled groups (control serum and anti-NGF) is expressed as a percentage of the control density.

\section{Anti-NGF reduces kindling-induced mossy fiber sprouting}

The anti-NGF IgG-treated kindled rats showed a significantly higher stratum oriens density compared to nonkindled control rats $(p<0.05)$, but a significantly lower density when compared to the control serum IgG-treated kindled rats $(p<0.001$; Fig. 3; see also Fig. $2 A-C$ ). The stratum oriens Timm staining density of the anti-NGF IgG infused, electrode-implanted but nonkindled group was not different from the control nonkindled animals (Fig. 3), indicating that anti-NGF did not alter the amount of Timm granules present in nonkindled rats. A 20\% increase in Timm granule density in the control serum IgG-treated kindled rats ( $p<0.01$, Fig. 5), as compared to control nonkindled rats, indicates mossy fiber sprouting evoked by kindling. However, the Timm granule density in anti-NGF IgG-treated kindled rats $(n-6)$ was reduced by half compared to the control serum IgG-treated kindled rats $(p<0.01 ;$ Fig. 5), and showed only a $10 \%$ increase in density over nonkindled rats $(p<0.05$; Fig. 5).

\section{ChAT immunostaining density}

Table 2 demonstrates that, in amygdala kindled rats that received 2 weeks of intraventricular anti-NGF IgG infusion $(n-4)$, ChAT immunostaining density of cholinergic neurons in the medial septum and vertical diagonal band of Broca was decreased $33.3 \%$ when compared to the control serum IgG infused, kindled rats $(n=4)$, the noninfused kindled control group $(n=3)$, or the nonkindled control group ( $n=3$ ); this result was statistically significant $(p<0.01$, one-way ANOVA with supplemental $t$ test). Kindling alone did not alter the ChAT immunostaining density of cholinergic neurons. Furthermore, no significant change ( $p>0.05$, Student's $t$ test) was found in the total number of ChAT-positive cell bodies in anti-NGF IgG-treated kindled rats (941 \pm 177$)$ compared to control serum IgG-treated kindled animals ( $916 \pm 94)$. Figure 6 shows representative samples of ChAT immunostained sections of control serum IgG-infused, kindled rats $(A)$; anti-NGF IgG-infused, kindled rats $(B)$; noninfused, kindled rats $(C)$; and noninfused, nonkindled rats $(D)$. Note the decrease in ChAT immunostaining in Figure $6 B$.

\section{Discussion}

We show in this study that intraventricular infusion of affinitypurified anti-NGF IgGs resulted in both a significant retardation of kindling and a significant inhibition of kindling-induced mossy fiber sprouting. This study provides the first evidence for neurotrophin involvement in kindling and in an associated sprouting process in the same brains.

We measured kindling-induced mossy fiber sprouting in area CA3 of the hippocampus using a new semiquantitative method of analysis based on Timm staining. The demonstration of mossy fiber sprouting after kindling is in agreement with earlier reports (Sutula et al., 1988; Represa et al., 1989; Cavazos et al., 1991; Represa and Ben-Ari, 1992; Represa et al., 1993), and specifically with the studies of Represa and colleagues in which they demonstrated mossy fiber sprouting in the same area (CA3), and an apparent formation of new synapses on the basilar dendrites of the CA3 pyramidal neurons.

Our findings are compatible with reports that neurotrophins 

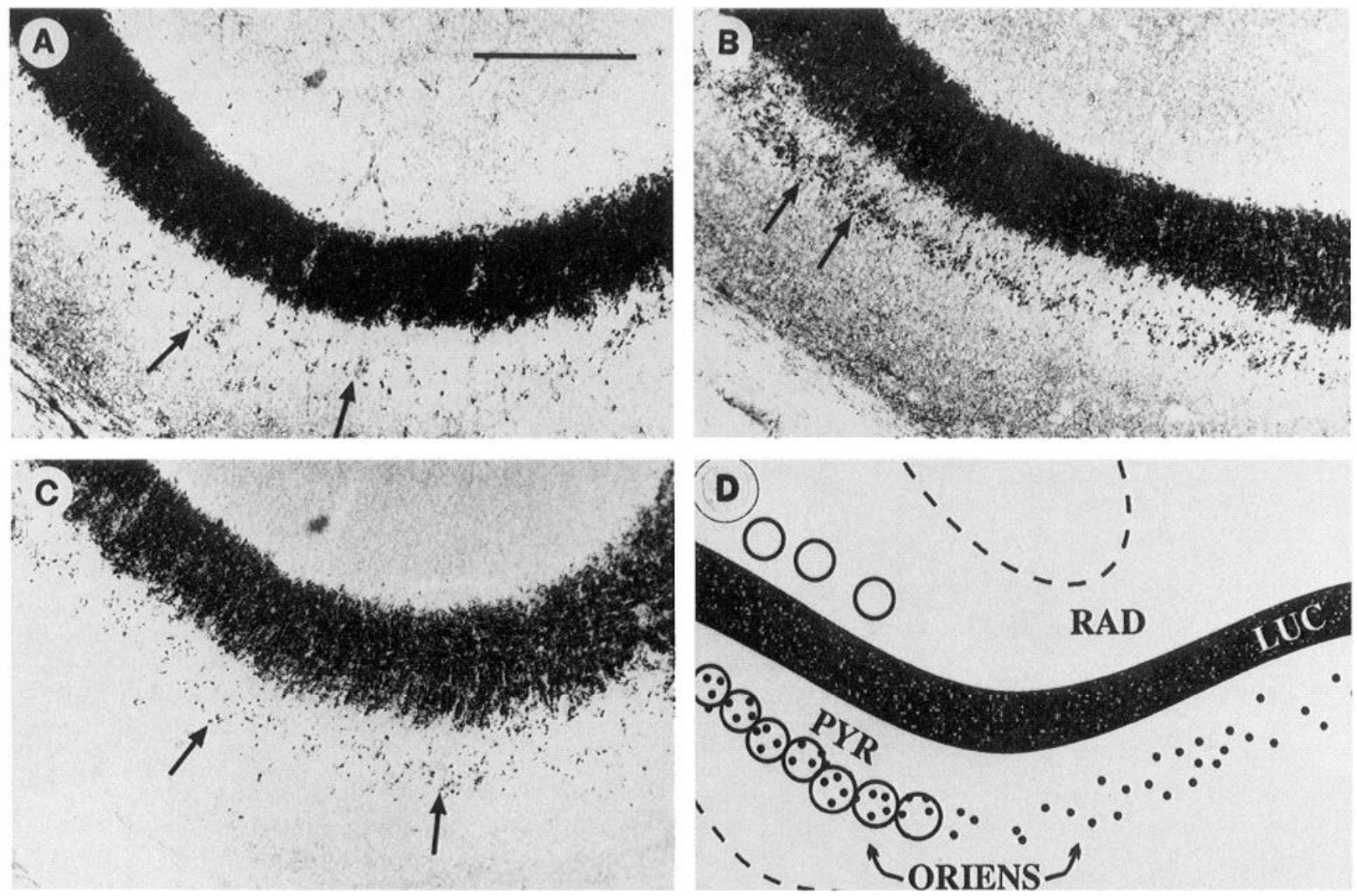

Figure 2. Mossy fiber sprouting in hippocampal area CA3. Timm's sulfide silver-stained horizontal brain sections from the medial-temporal hippocampus of an adult nonkindled control $(A)$, a control serum IgG-treated kindled $(B)$, and an anti-NGF IgG-treated kindled $(C)$ rat. An increased concentration of Timm granules, indicating mossy fiber sprouting, is visible in the stratum oriens of the kindled rat $(B)$, whereas this kindlinginduced mossy fiber sprouting is reduced following intraventricular anti-NGF IgG infusion $(C)$. $D$, A schematic drawing of the digitized image of the hippocampal area CA3 indicates a dark band of $\mathrm{Zn}^{2+}$-positive mossy fibers in the stratum lucidum (LUC); these fibers cross the pyramidal cell layer $(P Y R)$ and sprout into the stratum oriens $($ ORIENS), forming a band of Timm granules. The density measurements of the Timm granules were performed by placing an open circle cursor $\left(1.3 \mathrm{~cm}^{2}\right)$ at 20 adjacent positions along the stratum oriens (ORIENS), and 10 cursor placements in the stratum radiatum $(R A D)$ provided the background staining density. Scale bar, $200 \mu \mathrm{m}$.

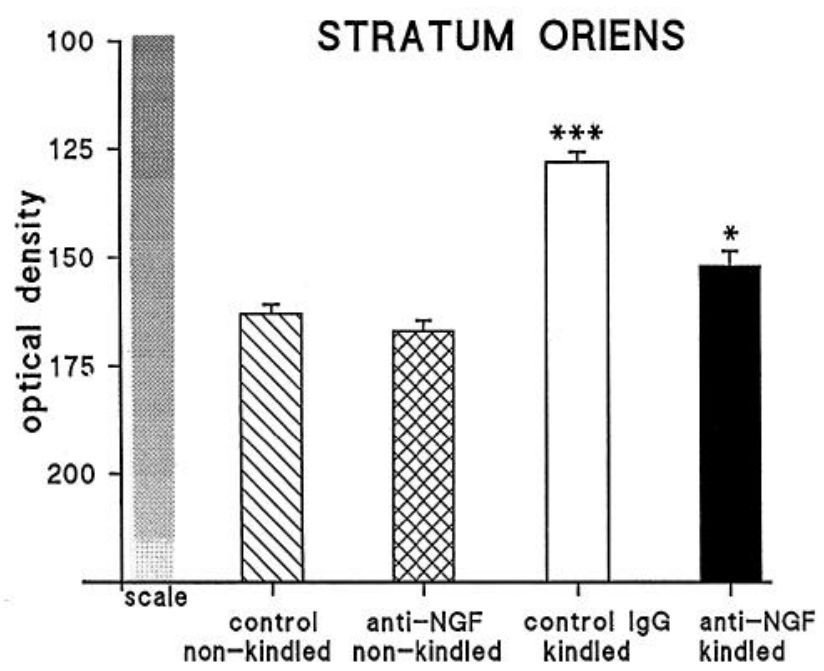

Figure 3. Stratum oriens Timm staining density. Kindled rats treated with control serum IgGs $(n=5)$ or anti-NGF IgGs $(n=6)$ show a higher density of Timm granules in the stratum oriens compared to nonimplanted, nonkindled control $(n=7)$ or anti-NGF IgG infused, electrode-implanted nonkindled control $(n=5)$ animals. However, the anti-NGF IgG-treated kindled rats show a lower stratum oriens density compared to the control serum IgG-treated kindled group. *, statistical significance $(p<0.05)$; $* * *, p<0.001$.

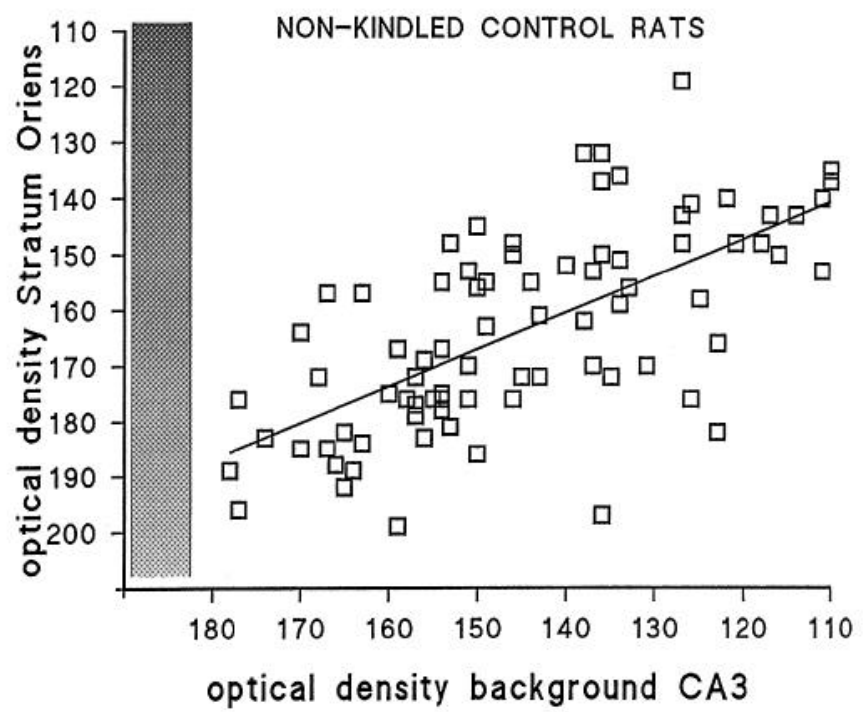

Figure 4. Timm staining density values of the stratum oriens and the stratum radiatum (background CA3) of control rats. Nonkindled rats without implanted electrodes were used to construct a regression line based upon 80 correlated values (seven rats; 10-12 hippocampal sections/rat). This regression line was used as a standard curve for comparisons of Timm granule density values of the stratum oriens in the kindled groups (Fig. 5). 


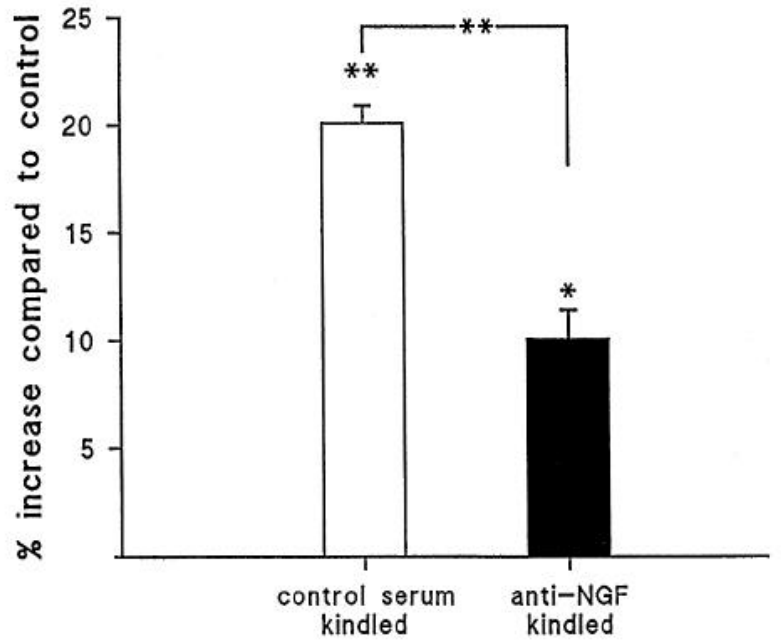

Figure 5. Anti-NGF reduction of kindling-induced mossy fiber sprouting. The stratum oriens density of the control serum $\operatorname{IgG}(n=5)$ and anti-NGF IgG $(n=6)$-treated kindled rats is now expressed as the percentage increase compared to nonimplanted, nonkindled controls $(n$ $=7$ ), and shows a significant increase in Timm granule density following kindling. Anti-NGF IgG treatment results in a significant reduction of this kindling-induced mossy fiber sprouting. *, statistical significance $(p<0.05)$; **, $p<0.01$.
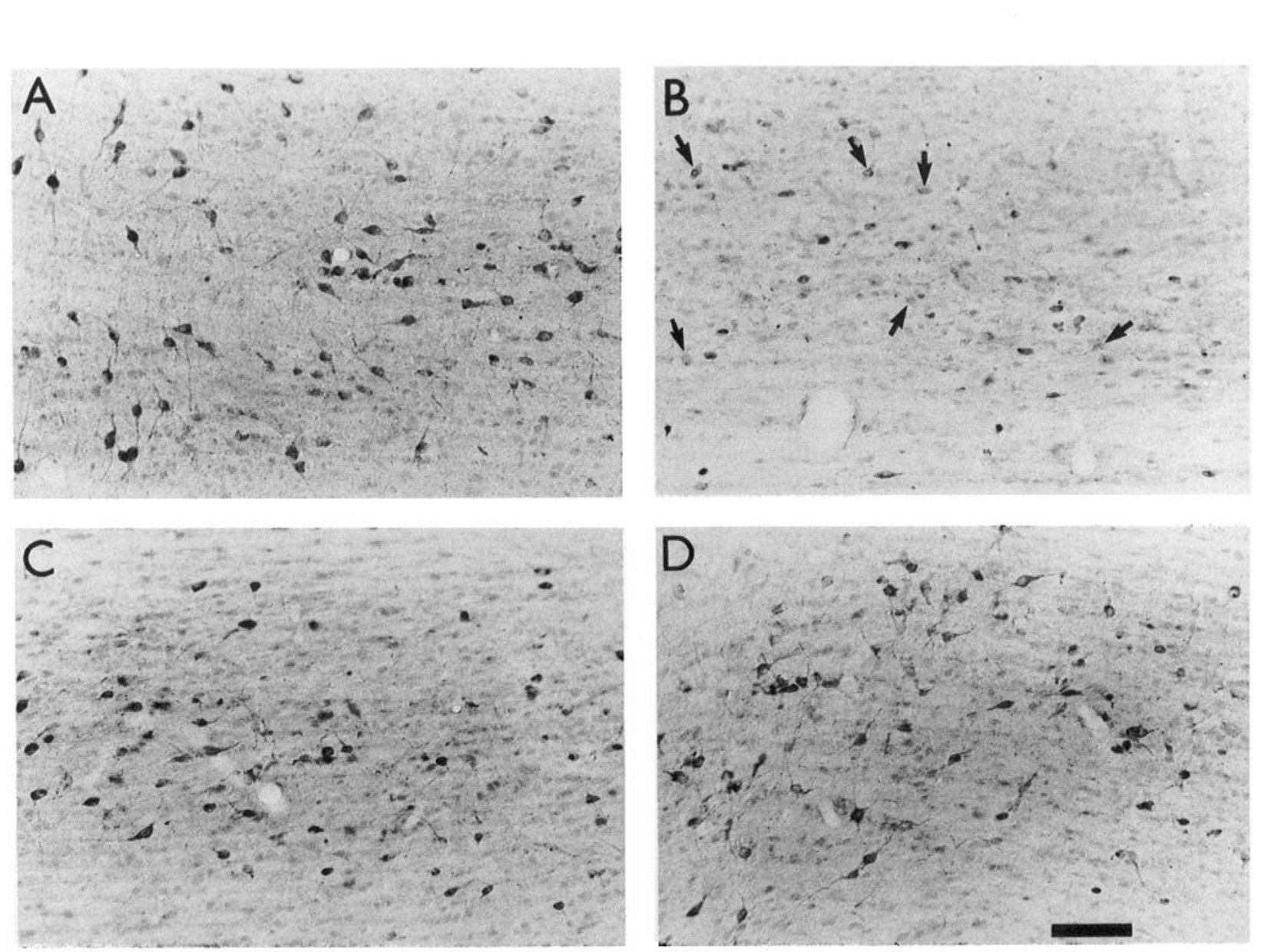

are specifically upregulated in a wide variety of seizure paradigms. In particular, there is a marked and transient increase of NGF and BDNF mRNA expression in the hippocampus following seizures induced by electrolytic lesion, systemic kainic acid (KA), or rapid kindling (Gall and Isackson, 1989; Zafra et al., 1990; Ernfors et al., 1991; Gall et al., 1991; Dugich-Djordjevic et al., 1992; Bengzon et al., 1993). A transient increase was also reported for trkB (BDNF receptor) mRNA and for trkB protein

\begin{tabular}{lll} 
Treatment & $n$ & Optical density \\
\hline Control serum IgG (2 weeks, i.c.v.), kindled & 4 & $53.1 \pm 4.2$ \\
Anti-NGF IgG (2 weeks, i.c.v.), kindled & 4 & $35.4 \pm 0.7^{* *}$ \\
No infusion, kindled & 3 & $53.6 \pm 0.6$ \\
No infusion, non-kindled & 3 & $53.5 \pm 0.4$
\end{tabular}

The optical density value was determined by subtracting the background density (35 measurements/section) from the average density of the (35-100) ChAT was then calculated based on measurements of 10-13 sections per animal; values shown are means per group \pm SEM.

** Statistically different from the control serum, kindled group and the two nontreated kindled and nonkindled control groups $(p<0.01$, one-way ANOVA nontreated kindled and nonk
with supplemental $t$ test).

Figure 6. ChAT immunostaining of cholinergic neurons in the medial septum and vertical diagonal band of Broca. Representative examples of $40 \mu \mathrm{m}$ basal forebrain sections from $(A)$ a kindled rat infused with control serum IgGs, $(B)$ a kindled rat infused with anti-NGF IgGs, $(C)$ a noninfused, kindled rat, and $(D)$ a noninfused, nonkindled rat. Note the decreased ChAT immunostaining in many neurons in panel B (arrows). Scale bar, $100 \mu \mathrm{m}$. 
immunoreactivity in the hippocampal pyramidal and dentate gyrus granule cells following a rapid kindling procedure (Merlio et al., 1993). Neurotrophin-3 mRNA remains unchanged (Ernfors et al., 1991) or is reduced after kindling stimulation (Bengzon et al., 1993).

We demonstrate that a continuous infusion of anti-NGF IgG over a 2 week period during the kindling procedure increases the number of stimulations required to reach the fully kindled state by $58 \%$. Our observation that antibody to NGF retards kindling confirms the results of Funabashi et al. (1988), who reported that intraventricular injection of antiserum to NGF delayed the development of amygdaloid kindling. The antiserum used by Funabashi et al. (1988) was not characterized with respect to its cross-reactivity with other neurotrophins. The antibody to NGF used in the present study has been characterized for potency of inhibition of NGF and cross-reactivity to BDNF and NT-3 in two types of in vitro biological assays. This antibody has been shown to block the ability of NGF, but not that of BDNF or NT-3, to support the survival of chick dorsal root ganglion neurons (R. Kolbeck and Y.-A. Barde, personal communication). We show in the present study that our anti-NGF IgG blocks both NGF- and NT-3-induced neurite outgrowth in mouse superior cervical or dorsal root ganglion neurons; however, it does not block BDNF-induced neurite outgrowth from mouse nodose ganglion neurons. Because of these in vitro results, we can rule out an effect on BDNF but not on NT-3 in our kindling model. However, the lack of antibody-mediated inhibition of NT-3 in the chick neuron survival assay referred to above, and the reported lack of upregulation of NT-3 by kindling (Ernfors et al., 1991; Bengzon et al., 1993), support our view that the effects reported here are due to inhibition of NGF, and not of BDNF or NT-3, activity.

The ability of anti-NGF treatment to significantly reduce kindling-induced mossy tiber sprouting is consistent with previous observations of anti-NGF inhibition of collateral sprouting of scptohippocampal fibers following entorhinal cortex lesion (Van der Zee et al., 1992). Furthermore, administration of anti-NGF IgG at one-tenth the concentration used in the present experiments fails to block this lesion-induced septohippocampal sprouting (C. E. E. M. Van der Zee, J. Fawcett, and J. Diamond, in preparation), arguing in favor of the specificity of the antibody's effects and the appropriateness of the administered dose in the present study. However, while the septohippocampal fibers are cholinergic, and are known to express both p75 and trkA NGF receptors (Koh et al., 1989; Vazquez and Ebendal, 1991; Bengzon et al., 1993; Steininger et al., 1993), the mossy fibers in the hippocampus are glutamatergic, and have not yet been shown to express NGF receptors. On the other hand, there is evidence for the presence of NGF receptor in noncholinergic brain areas: Venero and Hefti (1993) reported trkA mRNA expression by noncholinergic thalamic neurons, Pioro and Cuello (1990) demonstrated low-affinity NGF receptor immunoreactivity in colchicine-treated animals in the hippocampal CA3 pyramidal layer and the hilus of the dentate gyrus and Altar et al. (1991) reported high-affinity NGF binding sites in the dentate gyrus and area CA1 of the dorsal hippocampus. It is conceivable, therefore, that trkA and/or p75 receptors are present in low amounts in the hippocampal glutamatergic neurons, and responsible for an NGF-dependent sprouting of the glutamatergic mossy fibers.

Another possible explanation for anti-NGF inhibition of mossy fiber sprouting is that the effect is achieved by way of a reduction in the synthesis of acetylcholine $(\mathrm{ACh})$ in the basal forebrain cholinergic neurons. Such a reduction is supported by our finding that anti-NGF IgG treatment reduces ChAT immuInustaining by $33 \%$, in agreement with previous studies showing reduction of cholinergic markers as a result of intraventricular anti-NGF infusion (Vantini et al., 1989; Van der Zee et al. 1992, 1995). Anti-NGF treatment does not, however, reduce $\mathrm{AChE}$ fiber density in the dentate gyrus (Van der Zee et al., 1992). A reduced synthesis of $\mathrm{ACh}$ in the basal forebrain neurons would be anticipated to reduce cholinergically mediated synaptic drive of their target neurons, principally the granule cells of the dentate gyrus. It has already been shown that granule cell activation upregulates mRNA for BDNF (Lindefors et al., 1992), and that disruption of the cholinergic innervation causes a decreased BDNF mRNA expression throughout the hippocampal formation (Berzaghi et al., 1993; Lapchak et al., 1993). The result of antiNGF treatment, therefore, could well be a reduced release of $\mathrm{BDNF}$ from the granule cells, and a reduced sprouting response in the kindling paradigm.

Sprouting of the mossy fibers and the formation of new synapses are strongly correlated with the development, progression, and permanence of kindled seizures (Cavazos et al., 1991), and occur along the entire septotemporal axis of the hippocampus (Cavazos et al., 1992). The question remains, however, whether kindling-induced epileptogenesis and kindling-induced sprouting are causally linked. The activation of these systems during kindling may be responsible for evoking sprouting, or the mossy fiber sprouting and synaptic reorganization may contribute to and reinforce kindling epileptogenesis. Nlthough anti-NGF IgG suppressed both kindling and sprouting, kindling eventually did proceed to its normal maximal level (stage 5) in 9 of the 12 anti-NGF-treated rats, while sprouting was apparently permanently reduced by $50 \%$. Multiple neurotrophins may be involved in kindling. Thus, the simultaneous inhibition of these factors would probably be required to resolve the question of the exact relationship between sprouting and the kindled state.

\section{References}

Altar CA, Burton LE, Bennett GL, Dugich-Djordjevic MM (1991) Recombinant human nerve growth factor is biologically active and labels novel high-affinity binding sites in rat brain. Proc Natl Acad Sci USA 88:281-285.

Arnold P, Racine RJ, Wise R (1973) Effects of atropine, reserpine, 6-hydroxydopamine, and handling on seizure development in the rat. Exp Neurol 40:457-470.

Barde Y-A (1989) Trophic factors and neuronal survival. Neuron 2:1525-1534.

Bengzon J, Söderström S, Kokaia Z, Kokaia M, Ernfors P, Persson H, Ebendal T, Lindvall $O$ (1992) Widespread increase of nerve growth factor protein in the rat forebrain after kindling-induced seizures. Brain Res 587:338-342.

Bengzon J, Kokaia Z, Ernfors P, Kokaia M, Leanza G, Nilsson OG, Persson H, Lindvall O (1993) Regulation of neurotrophin and trkA, trkB and trkC tyrosine kinase receptor messenger RNA expression in kindling. Neuroscience 53:433-446.

Berzaghi MP, Cooper J, Castrén E, Zafra F, Sofroniew M, Thoenen H, Lindholm D (1993) Cholinergic regulation of brain-derived neurotrophic factor (BDNF) and nerve growth factor (NGF) but not neurotrophin-3 (NT-3) mRNA levels in the developing rat hippocampus. J Neurosci 13:3818-3826.

Cain DP (1983) Bidirectional transfer of electrical and carbachol kindling. Brain Res 260:135-138.

Cain DP, Desborough KA, McKitrick DJ (1988) Retardation of amygdala kindling by antagonism of NMDA-aspartate and muscarinic cholinergic receptors: evidence for the summation of excitatory mechanisms in kindling. Exp Neurol 100:179-187.

Cavazos JE, Golarai G, Sutula TP (1991) Mossy fiber synaptic reor- 
ganization induced by kindling: time course of development, progression, and permanence. J Neurosci 11:2795-2803.

Cavazos JE, Golarai G, Sutula TP (1992) Septotemporal variation of the supragranular projection of the mossy fiber pathway in the dentate gyrus of normal and kindled rats. Hippocampus 2:363-372.

Cavazos JE, Das I, Sutula TP (1994) Neuronal loss induced in limbic pathways by kindling: evidence for induction of hippocampal sclerosis by repeated brief seizures. J Neurosci 14:3106-3121.

Coughlin MD, Collins MB (1985) Nerve growth factor independent development of embryonic mouse sympathetic neurons in dissociated cell culture. Dev Biol 110:392-401.

Danscher G (1981) Histochemical demonstration of heavy metals: a revised version of the sulphide silver method suitable for both light and electronmicroscopy. Histochemistry 71:1-16.

Diamond J, Coughlin M, Holmes M (1992) Endogenous NGF and nerve impulses regulate the collateral sprouting of sensory axons in the skin of the adult rat. J Neurosci 12:1454-1466.

Dugich-Djordjevic MM, Tucco G, Willoughby DA, Najim I, Pasinetti G, Thompson RF, Baudry M, Lapchak PA, Hefti F (1992) BDNF mRNA expression in the developing rat brain following kainic acidinduced seizure activity. Neuron 8:1127-1138.

Ernfors P, Bengzon J, Kokaia Z, Persson H, Lindvall O (1991) Increased levels of messenger RNAs for neurotrophic factors in the brain during kindling epileptogenesis. Neuron 7:165-176.

Funabashi T, Sasaki H, Kimura F (1988) Intraventricular injection of antiserum to nerve growth factor delays the development of amygdaloid kindling. Brain Res 458:132-136.

Gall CM, Isackson PJ (1989) Limbic seizures increase neuronal production of messenger RN $\Lambda$ for nerve growth factor. Science 245:758761.

Gall CM, Murray K, Isackson PJ (1991) Kainic acid-induced seizures stimulate increased expression of nerve growth factor mRNA in rat hippocampus. Mol Brain Res 9:113-123.

Hagg T, Vahlsing HL, Manthorpe M, Varon S (1990) Nerve growth factor infusion into the denervated adult rat hippocampal formation promotes its cholinergic reinnervation. J Neurosci 10:3087-3092.

Houser CR (1992) Morphological changes in the dentate gyrus in human temporal lobe epilepsy. In: Epilepsy research, Suppl 7, The dentate gyrus and its role in seizures, Chap 16 (Ribak CE, Gall CM, Mody I, eds). Amsterdam: Flsevier.

Houser CR, Miyashiro JE, Swartz BE, Walsh GO, Rich JR, DelgadoEscueta AV (1990) Altered patterns of dynorphin immunoreactivity suggest mossy fiber reorganization in human hippocampal epilepsy. J Neurosci 10:267-282.

Koh S, Loy R (1988) Age-related loss of nerve growth factor sensitivity in rat basal forebrain neurons. Brain Res 440:396-401.

Koh S, Chang P, Collier TJ, Loy R (1989) Loss of NGF receptor immunoreactivity in basal forebrain neurons of aged rats: correlation with spatial memory impairment. Brain Res 498:397-404.

Lapchak PA, Araujo DM, Hefti F (1993) Cholinergic regulation of hippocampal brain-derived neurotrophic factor mRNA expression: evidence from lesion and chronic drug treatment studies. Neuroscience 52:575-585.

Lauterborn JC, Tran TMD, Isackson PJ, Gall C.M (1993) Nerve growth factor mRNA is expressed by GABAergic neurons in rat hippocampus. Neuroreport 5:273-276.

Lindefors N, Renfors P, Falkenberg T, Persson H (1992) Septal cholin ergic afferents regulate expression of brain-derived neurotrophic factor and $\beta$ - nerve growth factor mRNA in rat hippocampus. Exp Brain Res 88:78-90.

Lowenstein DH, Seren MS, Longo FM (1993) Prolonged increases in neurotrophic activity associated with kainate-induced hippocampal synaptic reorganization. Neuroscience 56:597-604.

Masukawa LM, Uruno K, Sperling M, O'Connor MJ, Burdette LJ (1992) The functional relationship between antidromically evoked field responses of the dentate gyrus and mossy fiber reorganization in temporal lobe epileptic patients. Brain Res 579:119-127.

McKinney MH, Parkinson A (1987) A simple non-chromatographic procedure to purify immunoglobulins from serum and ascites fluid. $\mathbf{J}$ Immunol Methods 96:271-278.

Merlio J-P, Ernfors P, Kokaia Z, Middlemas DS, Bengzon J, Kokaia M, Smith M-L, Siesjö BK, Hunter T, Lindvall O, Persson H (1993) Increased production of the trkB protein tyrosine kinase receptor after brain insults. Neuron 10:151-164.
Mobley WC, Schenker A, Shooter EM (1976) Characterization and isolation of proteolytically modified nerve growth factor. Biochemistry 15:5543-5551.

Paxinos G, Watson C (1982) The rat brain in stereotaxic coordinates. Sydney: Academic.

Petrides PE, Shooter EM (1986) Rapid isolation of the 7S-nerve growth factor complex and its subunits from murine submaxillary glands and saliva. J Neurochem 46:721-725.

Pioro EP, Cuello AC (1990) Distribution of nerve growth factor receptor-like immunoreactivity in the rat adult central nervous system. Effect of colchicine and correlation with the cholinergic system-I. Forebrain. Neuroscience 34:57-87.

Racine RJ (1972) Modification of seizure activity by electrical stimulation. II. Motor seizure. Electroencephalogr Clin Neurophysiol 32: 281-294.

Racine RJ, Burnham WM (1984) The kindling model. In: Electrophysiology of epilepsy, pp 153-171. London: Academic.

Represa A, Ben-Ari Y (1992) Kindling is associated with the formation of novel mossy fibre synapses in the CA3 region. Exp Brain Res 92: 69-78.

Represa A, Le Gall La Salle G, Ben-Ari Y (1989) Hippocampal plasticity in the kindling model of epilepsy in rats. Neurosci Lett 99:345350.

Represa A, Jorquera I, Le Gall La Salle G, Ben-Ari Y (1993) Epilepsy induced collateral sprouting of hippocampal mossy fibers: does it induce the development of ectopic synapses with granule cell dendrites? Hippocampus 3:257-268.

Sato M, Racine RJ, McIntyre DC (1990) Kindling: basic mechanisms and clinical validity. Electroencephalogr Clin Neurophysiol 76:459472.

Sloviter RS (1987) Decreased hippocampal inhibition and a selective loss of interneurons in experimental epilepsy. Science 235:73-76.

Spiller AE, Racine RJ (1994) The effect of kindling beyond the "stage 5 " criterion on paired-pulse depression and hilar cell counts in the dentate gyrus. Brain Res 635:139-147.

Steininger TL, Wainer BH, Klein R, Barbacid M, Palfrey HC (1993) High-affinity nerve growth factor receptor (Trk) immunoreactivity is localized in cholinergic neurons of the basal forebrain and striatum in the adult rat brain. Brain Res 612:330-335.

Sutula T, Xiao-Xian H, Cavazos J, Scott G (1988) Synaptic reorganization in the hippocampus induced by abnormal functional activity. Science 239:1147-1150.

Sutula T, Cascino G, Cavazos J, Parada I, Ramirez L (1989) Mossy fiber synaptic reorganization in the epileptic human temporal lobe. Ann Neurol 26:321-330.

Van der Zee CEEM, Fawcett J, Diamond J (1992) Antibody to NGF inhibits collateral sprouting of septohippocampal fibers following entorhinal cortex lesion in adult rats. J Comp Neurol 326:91-100.

Van der 'Zee CEEM, Lourenssen S, Stanisz J, Diamond J (1995) NGFdeprivation of adult rat brain results in cholinergic hypofunction and impaired spatial learning behavior. Eur J Neurosci 7:160-168.

Vantini G, Schiavo N, DiMartino A, Polato P, Triban C, Callegaro L, Toffano G, Leon A (1989) Evidence for a physiological role of nerve growth factor in the central nervous system of neonatal rats. Neuron $3: 267-273$.

Vazquez ME, Ebendal T (1991) Messenger RNAs for trk and the lowaffinity NGF receptor in rat basal forebrain. Neuroreport 2:593-596.

Venero JL, Hefti F (1993) TrkA NGF receptor expression by noncholinergic thalamic neurons. Neuroreport 4:959-962.

Westerberg V, Corcoran ME (1987) Antagonism of central but not peripheral cholinergic receptors retards amygdala kindling in rats. Exp Neurol 95:194-206.

Yamamori 'I' (1992) Molecular mechanisms for generation of neural diversity and specificity: roles of polypeptide factors in development of postmitotic neurons. Neurosci Res 12:545-582.

Zafra F, Hengerer B, Leibrock J, Thoenen H, Lindholm D (1990) Activity dependent regulation of BDNF and NGF mRNAs in the rat hippocampus is mediated by non-NMDA glutamate receptors. EMBO J 9:3545-3550.

Zafra F, Castrén E, Thoenen H, Lindholm (1991) Interplay between glutamate and gamma-aminobutyric transmitter systems in the physiological regulation of brain-derived neurotrophic factor and nerve growth factor synthesis in hippocampal neurons. Proc Natl Acad Sci USA 88: $10037-10041$. 